Kredo 4 (2021)
KREDO: Jurnal Ilmiah Bahasa dan Sastra
Terakreditasi Sinta 4 berdasarkan Keputusan Direktorat
Jenderal Penguatan Riset dan Pengembangan,
Kementerian Riset, Teknologi dan Pendidikan Tinggi
Republik Indonesia
Nomor: 23/E/KPT/2019. 08 Agustus 2019
https://jurnal.umk.ac.id/index.php/kredo/index

\title{
PROGRAM TOWN4KIDS UNTUK MEMPERKAYA PENGUASAAN KOSAKATA SISWA
}

\author{
Retno Dwigustini ${ }^{1,}$ Susilawati $^{2}$ \\ ${ }^{1}$ retno.rgu@bsi.ac.id \\ ${ }^{2}$ susilawatitoro@stkipkusumanegara.ac.id \\ ${ }^{1}$ Universitas Bina Sarana Informatika \\ ${ }^{2}$ STKIP Kusuma Negara
}

\section{Info Artikel \\ Sejarah Artikel \\ Diterima \\ 11 September 2020 \\ Disetujui \\ 18 Oktober 2020 \\ Dipublikasikan \\ 5 April 2021 \\ Keywords \\ action research, vocabulary acquisition, \\ Town4kids \\ multimedia games}

\section{Kata Kunci}

penelitian

tindakan,

peningkatan

penguasaan

kosakata,

permainan

bahasa

multimedia

Town4kids
:

:

The objective of this action research study is to find out whether or not games in Town4kids multimedia laboratory (such as memory game, listen and unscramble game, name the picture, find the word, matching similar pictures), can enhance students' English vocabulary mastery. The research was conducted at Insan Madani Primary School in Bekasi. Twenty-two students of $4^{\text {th }}$ grade students were involved in this study. Observation, and pretest-posttest were used to collect the data. This research used two kinds of data analysis; they are qualitative and quantitative data analysis. Qualitative data were obtained using Kemmis \& Mc Taggart design in two cycles. Quantitative data were calculated using t-test for non-independent sample. The result of this research indicated that: (1) there is a significant improvement of English vocabulary acquisition; (2) games in town4forkids

: multimedia laboratory give positive and effective effects on students'vocabulary mastery; (3) the use of games in Town4kids multimedia laboratory creates fun and active learning for the students. It is recommended for teachers to upgrade their pedagogical competence, while for future researchers, preparing sufficient learning material and time in class management are suggested.

\section{Abstrak}

Tujuan penelitian tindakan kelas ini adalah untuk menemukan apakah permainan dalam laboratorium multimedia Town4kids (seperti as memory game, listen and unscramble game, name the picture, find the word, matching similar pictures) mampu meningkatkan penguasaan kosakata bahasa Inggris siswa. Penelitian ini dilakukan di Sekolah Dasar Insan Madani Bekasi. 22 orang siswa terlibat dalam penelitian ini. Observasi dan pretest-posttest digunakan untuk pengumpulan data. Penelitian ini menggunakan dua jenis analisis data: kualitatif dan kuantitatif. Data kualitatif dikumpulkan menggunakan desain Kemmis \& McTaggart dalam dua siklus. Data kuantitatif dihitung dengan menggunakan uji t-test untuk non-independent sampel. Hasil penelitian ini menunjukkan bahwa: 1) ada peningkatan yang signifikan dalam pemerolehan kosakata bahasa Inggris siswa; 2) permainan dalam laboratorium multimedia Town4kids memberikan efek yang positif dan efektif terhadap penguasaan kosakata siswa; 3) penggunaan permainan di Town4kids menciptakan pembelajaran yang menyenangkan dan aktif untuk siswa. Penelitian ini merekomendasikan guru untuk bisa meningkatkan kompetensi pedagogik, sementara untuk peneliti berikutnya, disarankan untuk mempersiapkan materi pembelajaran yang cukup dan waktu dalam pengelolaan kelas. 


Kredo 4 (2021)
KREDO: Jurnal Ilmiah Bahasa dan Sastra
Terakreditasi Sinta 4 berdasarkan Keputusan Direktorat
Jenderal Penguatan Riset dan Pengembangan,
Kementerian Riset, Teknologi dan Pendidikan Tinggi
Republik Indonesia
Nomor: 23/E/KPT/2019. 08 Agustus 2019
https://jurnal.umk.ac.id/index.php/kredo/index

\section{PENDAHULUAN}

Laboratorium

Town4kids merupakan sebuah laboratorium bahasa yang baru di sekolah Insan Madani. Laboratorium multimedia ini mulai digunakan pada siswa kelas 1 s.d kelas 6. Program multimedia ini berasal dari Singapura, yang bernama Town4kids. Sistem laboratorium bahasa ini sangat berbeda dengan labolatorium bahasa yang banyak digunakan oleh sekolah-sekolah di Indonesia, tidak menggunakan banyak komputer, tetapi hanya satu komputer master untuk guru dan papan tulis yang diletakan sebuah mimio, yang berfungsi sebagai layar sentuh. Pada program multimedia ini terdapat banyak program pembelajaran, diantaranya: lagu, bercerita, permainan bahasa, gambar, dan lain sebagainya.

Laboratorium bahasa ini mempunyai peranan penting dalam proses pembelajaran bahasa Inggris di Sekolah Dasar Model Insan Madani, khususnya dalam memfasilitasi proses pembelajaran kosa kata. Dengan adanya laboratorium bahasa ini membantu siswa belajar kosa kata lebih mudah dan menarik. Mereka dapat menyentuh layar komputer untuk belajar kosakata melalui berbagai permainan bahasa yang tersedia. Sehingga siswa tidak akan merasa bosan. Permainan bahasa dianggap mampu memberikan variasi dalam proses pembelajaran kosakata. Permainan bahasa yang dapat digunakan di laboratorium ini antara lain find the word, listen and unscramble, name the picture, flip and match, catch and spell, memory game dan sebagainya.

Bagi siswa sekolah dasar, belajar kosakata melalui permainan bahasa sangat menyenangkan. Menurut Piaget (dikutip oleh Slavin, 2006), ciri pokok perkembangannya anak mulai berpikir secara logis tentang kejadian-kejadian konkret. Ciri dari tahapan antara lain adaptasi dengan gambaran yang menyeluruh, klasifikasi, penalaran, dan sebagainya. Sehingga dapat diartikan bahwa anak-anak usia dini antara 7 sampai 12 tahun mempunyai kemampuan untuk mengadaptasi gambar dengan mengembangkan logika mereka untuk menerima apa yang telah dilihat. Siswa kelas IV masih memiliki keinginan untuk bermain dan hal ini bisa dimanfaatkan untuk memfasilitasi proses belajar kosakata di laboratorium melalui permainan bahasa. Sehingga suasana belajar bisa lebih hidup dan interaktif. Dari bermain sambil belajar siswa mendapatkan makna dari proses pembelajaran yang dilakukan. Kosakata yang telah siswa pelajari bisa diterapkan dalam kehidupan keseharian. Maka proses belajar mereka lebih bermakna dan bermanfaat karena dapat 


Kredo 4 (2021)
KREDO: Jurnal Ilmiah Bahasa dan Sastra
Terakreditasi Sinta 4 berdasarkan Keputusan Direktorat
Jenderal Penguatan Riset dan Pengembangan,
Kementerian Riset, Teknologi dan Pendidikan Tinggi
Republik Indonesia
Nomor: 23/E/KPT/2019. 08 Agustus 2019
https://jurnal.umk.ac.id/index.php/kredo/index

menerapkan bahasa Inggris dalam komunikasi sehari-hari.

\section{KAJIAN TEORI}

Berbeda dengan bayi/balita yang belajar bahasa ibunya, pembelajar bahasa kedua sudah mempelajari dan mengetahui bagaimana kategori budaya mereka. Dengan kata lain, pembelajar bahasa kedua memakai jalan pintas dalam proses untuk memahami dunia sekitarnya dan dengan langsung belajar kosakata dari bahasa kedua dengan membuat pemetaan kosakata tersebut secara langsung kedalam bahasa ibunya. Richard dan Renandya menjelaskan "Vocabulary is a core component of language proficiency and provides much of the basis for how well learners speak, listen, read and write" (Richards \& Renandya, 2003) Kosakata diartikan sebagai komponen bahasa yang mendasar. Walaupun dalam bahasa Inggris ada 4 kemampuan dasar, yaitu menulis, membaca, mendengar, dan berbicara, namun penguasaan kosakata merupakan kebutuhan mendasar untuk menguasai ke 4 kemampuan tersebut.

Kosakata bisa juga didefinisikan sebagai isi dan fungsi yang terdapat dalam sebuah bahasa, karenanya kosakata merupakan hal yang tak terpisahkan dari pemahaman, kegiatan berbicara. Membaca serta menulis. Kosakata sederhananya bisa dikatakan sebagai kata yang bermakna ketika didengar dan dilihat ketika kata-kata tersebut digunakan untuk berkomunikasi.

Penguasaan kosakata menurut Heaton (1975) bisa dibagi menjadi dua kategori, yakni kosakata aktif dan kosakata pasif. Kosakata aktif bisa terdeteksi manakala mereka diutarakan tanpa proses berpikir panjang, sementara kosakata pasif adalah kata yang hampir tidak digunakan oleh seseorang namun bisa menyebabkan adanya respon jika kata tersebut didengar atau dibaca.

Djiwandono (2008) mengatakan bahwa penguasaan kosakata dalam peningkatan keterampilan berbahasa memiliki kaitan dengan dua hal berikut: penguasaan kosakata pasif reseptif dan aktif produktif. Penguasaan kosakata pasif reseptif hanya berkisar di kemampuan memahami kata tanpa kemampuan menggunakan kata tersebut. Seseorang yang berada pada tingkatan pemahaman ini hanya mampu mengidentifikasi makna kata tanpa mampu menggunakan kata tersebut untuk berkomunikasi. Sementara penguasaan kosakata aktif produktif merupakan pemahaman seseorang terhadap makna kata sekaligus penggunaan kata tersebut untuk mengekspresikan ide dan gagasan.

Berdasarkan pernyataan di atas dapat diketahui bahwa dalam pembelajaran bahasa di sekolah 


Kredo 4 (2021)
KREDO: Jurnal Ilmiah Bahasa dan Sastra
Terakreditasi Sinta 4 berdasarkan Keputusan Direktorat
Jenderal Penguatan Riset dan Pengembangan,
Kementerian Riset, Teknologi dan Pendidikan Tinggi
Republik Indonesia
Nomor: 23/E/KPT/2019. 08 Agustus 2019
https://jurnal.umk.ac.id/index.php/kredo/index

keterampilan membaca dan menyimak atau mendengarkan merupakan bagian dari kosakata pasif reseptif. Sedangkan keterampilan berbicara dan menulis termasuk dalam klasifikasi penguasaan kosakata aktif produktif. Pengembangan kosakata siswa yang berasal dari penyerapan informasi dari pihak lain termasuk dalam klasifikasi penguasaan kosakata pasif reseptif. Sedangkan penguasaan kosakata aktif produktif berupa pengajaran siswa dalam berbahasa.

Jadi dapat disimpulkan bahwa penguasaan kosakata merupakan perbendaharaan seseorang tentang katakata dalam berbagai bidang yang dapat digunakan dalam percakapan, sehingga proses komunikasi dapat berjalan dengan lancar dan pesan yang dimaksudkan dapat tersampaikan.

Mengenai pemerolehan bahasa kedua (bahasa Inggris) pertama bagi anak, menurut O'Grady, (2005): “Most children start producing words sometime between the ages of eight and twelve months or so, and many children have ten words in their vocabulary by the age of fifteen months. Things gradually pick up speed from that point on. Whereas an eighteen - month - old child may learn only one or two new words a day. A four - years - old will often acquire a dozen, and a seven - years - old will pick up as many as twenty". Hampir semua anak mulai mengenal kata antara usia delapan sampai dengan dua belas bulan, dan banyak anak yang memiliki sepuluh kata pada usia lima belas bulan. Pada usia delapan belas bulan, anak hanya dapat mempelajari satu sampai dua kata baru dalam sehari, tetapi pada usia empat tahun anak akan memperoleh banyak kata baru, bahkan pada usia tujuh tahun, anak akan semakin banyak memperoleh kata baru sampai ia berusia dua puluh tahun.

Di dalam bahasa Inggris, terdapat 3 jenis kata: kata kerja, kata sifat, dan kata benda. Lebih detailnya, Thomson \& Martinet (1986) mengelompokkan kata benda ke dalam beberapa kategori: (a) common nouns, misalnya: chair, human, kid, etc.; (b) proper nouns, contoh: Oxford, Manchester, Mr. John, Kimberley, etc.; (c) abstract nouns, misalnya kindness, hospitality, curiousity, etc. Penguasaan kosakata anak dari usia satu tahun sampai pada dua belas tahun akan mengalami perkembangan. Penguasaan kosakata benda dapat mereka peroleh dengan cara mendengarkan orang lain berbicara atau melihat benda-benda di sekeliling mereka yang ditemui dalam kehidupan sehari-hari. Finegan (2008) menyatakan verbs has a set of related forms (talk, talks, talked, talking) and the basic form - the one without an ending - can be preceded by 'can' or 'will'. Bagi Hornby (1994), adjective adalah kata yang mendeskripsikan seseorang atau 


Kredo 4 (2021)
KREDO: Jurnal Ilmiah Bahasa dan Sastra
Terakreditasi Sinta 4 berdasarkan Keputusan Direktorat
Jenderal Penguatan Riset dan Pengembangan,
Kementerian Riset, Teknologi dan Pendidikan Tinggi
Republik Indonesia
Nomor: 23/E/KPT/2019. 08 Agustus 2019
https://jurnal.umk.ac.id/index.php/kredo/index

sesuatu, misalnya: kecil, pintar, halus, di mana kata-kata ini disematkan pada kata benda berupa orang atau sesuatu.

Menurut Hadfield (2009), "a game is an activity with rules, a goal and an element of fun". Permainan bahasa merupakan kegiatan yang menyenangkan bagi anak-anak meskipun demikian permainan bahasa tetap memiliki aturan permainan dan tujuan akhir pembelajaran. Mengajarkan bahasa asing kepada pemula apalagi kepada siswa sekolah dasar berbeda dengan mengajarkan bahasa asing kepada siswa sekolah lanjutan. Anak usia dini akan belajar banyak apabila mereka tertarik kepada materi dan cara pengajarannya. Salah satu cara untuk membuat siswa tertarik terhadap bahan ajar serta termotivasi melakukan kegiatan pembelajaran adalah melalui permainan. Dengan permainan, siswa dibantu dan didorong untuk mempertahankan ketertarikan akan kegiatan mereka.

Menurut Hadfield (2009) permainan bahasa merupakan sebuah aktivitas yang terdiri dari sebuah peraturan, sebuah tujuan dan elemen kesenangan, ada 2 jenis permainan bahasa: competitive games dan cooperative games. Competitive games merupakan sebuah permainan bahasa dimana para pemainnya harus menjadi yang pertama mencapai tujuan secara individu, sedangkan cooperative games adalah sebuah permainan bahasa di mana para pemainnya harus bekerjasama untuk mencapai tujuan.

Menurut Harmer (2007), ada banyak permainan bahasa yang dapat menggunakan kosa kata. Diantaranya ada 3 jenis permainan bahasa menurut Harmer, Pictionary (pemain harus menggambar kata-kata yang ditunjukkan dan anggota tim lainnya diharuskan menebak kata apa itu), permainan kedua disebut Call my bluff dan permainan ketiga disebut Charades (pemain harus menirukan judul film, buku ataupun drama, kemudian anggota tim lain menebak judul film, buku atau drama tersebut).

Multimedia adalah pemanfaatan komputer untuk membuat dan menggabungkan teks, grafik, audio, gambar bergerak (video dan animasi) dengan menggabungkan link dan tool yang memungkinkan pemakai melakukan navigasi, berinteraksi, berkreasi dan berkomunikasi (Hornby, 1994). Dalam definisi ini terkandung empat komponen penting multimedia. Pertama, harus ada komputer yang mengkoordinasikan apa yang dilihat dan didengar, yang kedua, harus ada link yang menghubungkan kita dengan informasi, ketiga harus ada alat navigasi yang memandu kita, dan keempat, multimedia menyediakan tempat kepada 


Kredo 4 (2021)
KREDO: Jurnal Ilmiah Bahasa dan Sastra
Terakreditasi Sinta 4 berdasarkan Keputusan Direktorat
Jenderal Penguatan Riset dan Pengembangan,
Kementerian Riset, Teknologi dan Pendidikan Tinggi
Republik Indonesia
Nomor: 23/E/KPT/2019. 08 Agustus 2019
https://jurnal.umk.ac.id/index.php/kredo/index

kita untuk mengumpulkan, memproses dan mengkomunikasikan informasi.

Menurut Munir (2009), multimedia adalah kumpulan media berbasis komputer dan sistem komunikasi yang memiliki peran untuk membangun, menyimpan, menghantarkan dan menerima informasi dalam bentuk teks, grafik, audio, dan sebagainya. Berdasarkan teori tersebut maka dapat disimpulkan Multimedia merupakan kombinasi teks, gambar, audio, suara, animasi, dan video yang disampaikan melalui sebuah komputer atau alat elektronik lainnya.

Mills (2003) menyebutkan bahwa penelitian tindakan sebagai penelitian sistematis yang dilakukan oleh guru yang merangkap sebagai peneliti, kepala sekolah, konselor sekolah, atau stakeholder pendidikan lainnya dalam pembelajaran sebagai usaha untuk mengumpulkan informasi bagaimana sekolah dijalankan, bagaimana guru mengajar dan bagaimana siswa belajar di sekolah.

Gay \& Mills (2009) memiliki kecenderungan untuk mengatakan bahwa penelitian tindakan adalah penelitian yang dilakukan oleh guru untuk diri mereka sendiri tanpa ada pengaruh dari pihak lain. Jenis penelitian ini melibatkan guru dalam beberapa tahap penelitian, yakni: mengidentifikasi ranah dari fokus penelitian, mengumpulkan data, menganalisis dan menafsirkan data serta mengembangkan rencana tindakan.

\section{METODE PENELITIAN}

Penelitian tindakan ini dilaksanakan di SD Model Insan Madani, Bekasi pada siswa kelas 4. Penelitian ini dilakukan dalam kurun waktu 5 bulan. Penelitian ini diselesaikan dalam 2 siklus, menyesuaikan dengan jadwal pembelajaran bahasa Inggris di sekolah tersebut.

Penelitian ini dikategorisasikan sebagai penelitian tindakan. Penelitian tindakan yang dilakukan oleh peneliti dimaksudkan untuk melakukan perbaikan, pengembangan atau peningkatan sisi kognitif siswa di kelas. Peningkatan sisi kognitif yang dimaksudkan adalah yang peningkatan kosakata bahasa Inggris siswa melalui permainan bahasa yang memanfaatkan laboratorium multimedia Town4kids.

Metode penelitian yang peneliti gunakan adalah kualitatif sekaligus kuantitatif dengan memperhatikan partisipasi dan kolaborasi. Desain penelitian yang digunakan mengacu pada rancangan yang dipaparkan oleh Kemmis dan McTaggart yaitu desain dengan 2 siklus. Masing-masing siklus dirancang dalam 4 langkah berikut: 


Kredo 4 (2021)
KREDO: Jurnal Ilmiah Bahasa dan Sastra
Terakreditasi Sinta 4 berdasarkan Keputusan Direktorat
Jenderal Penguatan Riset dan Pengembangan,
Kementerian Riset, Teknologi dan Pendidikan Tinggi
Republik Indonesia
Nomor: 23/E/KPT/2019. 08 Agustus 2019
https://jurnal.umk.ac.id/index.php/kredo/index

perumusan masalah dan perencanaan tindakan, pelaksanaan tindakan dan observasi, refleksi hasil tindakan dan observasi, dan revisi rencana tindakan untuk siklus berikutnya.

Pada dasarnya model rancangan penelitian ini meliputi perencanaan (planning), pelaksanaan tindakan (acting), pengamatan (observing) dan refleksi (reflecting). Semua langkah tersebut dilakukan dalam sebuah siklus sebagai sebuah putaran langkah penelitian.

Subyek dalam penelitian ini adalah siswa kelas IV SD Model Insan Madani Bekasi dengan jumlah siswa sebanyak 22 orang. Terpilihnya kelas IV sebagai model penelitian dikarenakan siswa kelas IV ini merupakan para siswa dimana berdasarkan hasil nilai para siswa ketika mereka di kelas III sangat menurun, berbeda jauh dengan siswa kelas I dan II.

Peneliti dalam penelitian ini bertindak sebagai pelaksana sekaligus pengamat penelitian atau active participant. Peneliti melaksanakan proses KBM, pengamatan, dan menerima kritik serta masukan dari kolaborator untuk perbaikan dan peningkatan proses pembelajaran yang menjadi fokus dalam kegiatan penelitian (Mills, 2003).

Tahap intervensi tindakan mengacu pada model Kemmis \& McTaggart (1982). Adapun langkah- langkah penelitian tersebut sebagai berikut:

1. Merumuskan Masalah dan Merencanakan Tindakan. Dalam merumuskan masalah dan merencanakan tindakan yang akan dilakukan dalam penelitian, peneliti terlebih dahulu mengadakan observasi atau pengamatan awal

2. Melaksanakan tindakan dan pengamatan/monitoring. Setelah peneliti selesai merumuskan masalah dan merencanakan tindakan, tahap selanjutnya yang harus dilakukan adalah melaksanakan tindakan penelitian. Setiap tindakan dalam penelitian dilakukan dengan pengamatan yang teliti. Pengamatan dilakukan oleh peneliti dan guru kelas sebagai kolaborator.

3. Melaksanakan Tindakan dan Pengamatan/Monitoring

Setelah peneliti selesai merumuskan masalah dan merencanakan tindakan, tahap selanjutnya yang harus dilakukan adalah melaksanakan tindakan penelitian. Setiap tindakan dalam penelitian dilakukan dengan pengamatan yang teliti. Pengamatan dilakukan oleh peneliti dan guru kelas sebagai kolaborator.

Sebelum melakukan penelitian, peneliti melakukan tes pra-test terlebih dahulu serta membuat kisi - kisi 


Kredo 4 (2021)
KREDO: Jurnal Ilmiah Bahasa dan Sastra
Terakreditasi Sinta 4 berdasarkan Keputusan Direktorat
Jenderal Penguatan Riset dan Pengembangan,
Kementerian Riset, Teknologi dan Pendidikan Tinggi
Republik Indonesia
Nomor: 23/E/KPT/2019. 08 Agustus 2019
https://jurnal.umk.ac.id/index.php/kredo/index

instrumen penilaian. Kisi-kisi instrumen dibuat dengan tujuan untuk mempermudah dan mengoptimalkan soal-soal yang akan diteskan. Ada 25 soal yang akan diujikan sebagai instrumen dalam penelitian tindakan ini. Soal-soal tersebut didistribusikan dalam empat langkah ranah Bloom, yaitu $\mathrm{C} 1$ (mengingat), $\mathrm{C} 2$ (mengerti), $\mathrm{C} 3$ (menerapkan), C4 (menganalisis).

Tabel 1. Kisi - kisi Instrumen Pengusaan Kosakata

\begin{tabular}{ll}
\hline Kosakata & $\begin{array}{l}\text { Aspek Penilaian dan Jumlah } \\
\text { Nomor Soal }\end{array}$
\end{tabular}

\begin{tabular}{|c|c|c|c|c|c|}
\hline & $\mathrm{C} 1$ & C2 & $\mathrm{C} 3$ & $\mathrm{C} 4$ & \\
\hline $\begin{array}{l}\text { Kosakata } \\
\text { benda }\end{array}$ & 1,5 & $\begin{array}{l}8, \\
20\end{array}$ & $\begin{array}{l}12, \\
24\end{array}$ & $\begin{array}{l}4, \\
17\end{array}$ & 8 \\
\hline $\begin{array}{l}\text { Kosakata } \\
\text { kerja }\end{array}$ & $\begin{array}{l}2 . \\
15\end{array}$ & $\begin{array}{l}10, \\
14\end{array}$ & $\begin{array}{l}7, \\
16\end{array}$ & $\begin{array}{l}23, \\
9, \\
25\end{array}$ & 9 \\
\hline
\end{tabular}

\begin{tabular}{llllcl}
\hline $\begin{array}{l}\text { Kosakata } \\
\text { sifat }\end{array}$ & 3, & 13. & 6, & 22, & 8 \\
& 11. & 21 & 19 & 18 & \\
\hline Jumlah & 6 & 6 & 6 & 7 & 25 \\
\hline
\end{tabular}

Soal yang akan digunakan dalam tes penguasaan kosakata bahasa Inggris pada penelitian tindakan sebelumnya akan diuji validitas dan reabilitasnya. Uji validitas akan dilakukan oleh para ahli atau pakar yang dalam hal ini adalah pembimbing. Uji validitas dilakukan dengan menggunakan rumus korelasi biseriat titik yang digunakan untuk menguji soal dalam bentuk pilihan ganda. Soal tes penguasaan kosakata bahasa Inggris yang akan diujicobakan sebanyak 40 soal. Pelaksanaan uji coba dilaksanakan pada siswa kelas IV yang lain. 40 butir soal tersebut diujicobakan kepada 20 orang siswa dalam waktu 60 menit.

Perhitungan dengan rumus korelasi menunjukkan nilai $r_{\text {hitung }}$ diatas nilai $r_{\text {tabel }}$ ( $\mathrm{r}_{\text {hitung }} \geq \mathrm{r}_{\text {table }}$ ) dengan taraf signifikansi $5 \%=0.468$ dan $1 \%=0.590$. Hasil uji validasi menunjukkan 25 soal yang valid dari 40 soal yang diujicobakan. 25 soal tersebut mewakili kosakata benda sebanyak $9(1,4,5,8,12,15,17,20$, 24), kosakata kerja 8 soal $(2,6,9,10,13$, $14,18,25)$, dan kosakata sifat $8(3,7$, $11,16,21,22,23)$.

Sedangkan untuk mengetahui reliabilitas soal penguasaan kosakata bahasa Inggris, peneliti menguji reliabilitas instrumen dengan rumus perhitungan koefisien reliabilitas dengan menggunakan rumus Kuder Richardson20 (KR-20). Rumus tersebut digunakan untuk menguji reabilitas soal pilihan ganda. Hasil perhitungan KR-20 menunjukkan reliabilitas soal sebesar 0,963 di mana $r_{\text {hitung }}$ lebih tinggi dari nilai $r_{\text {tabel }}(0.468 \leq 0.963 \geq 0.590)$. Hasil ini menandakan nilai reliabilitas yang tinggi dari soal-soal yang diujikan. Selanjutnya, peneliti menggunakan instrumen lain dalam mengumpulkan 


Kredo 4 (2021)
KREDO: Jurnal Ilmiah Bahasa dan Sastra
Terakreditasi Sinta 4 berdasarkan Keputusan Direktorat
Jenderal Penguatan Riset dan Pengembangan,
Kementerian Riset, Teknologi dan Pendidikan Tinggi
Republik Indonesia
Nomor: 23/E/KPT/2019. 08 Agustus 2019
https://jurnal.umk.ac.id/index.php/kredo/index

data, yakni observasi, wawancara dan kuisioner (Madya, 1994).

\section{HASIL DAN PEMBAHASAN}

\section{Tahap Pra-Observasi}

Dalam tahapan ini, peneliti melakukan observasi untuk melihat apakah SD Model Insan Madani memenuhi kriteria untuk dijadikan tempat penelitian sesuai dengan fokus penelitian yang sudah ditetapkan. Data mengenai sekolah didapat dengan wawancara dan observasi. Hasilnya menunjukkan bahwa sekolah ini memenuhi kriteria dan mendukung kebutuhan penelitian.

\section{Tahap Pelaksanaan}

Penelitian tindakan kelas ini dilaksanakan dalam 2 siklus. Masingmasing siklus terdiri dari 4 pertemuan. Masing-masing pertemuan meliputi kegiatan perencanaan, pelaksanaan tindakan, pengamatan, refleksi dan dilengkapi dengan revisi.

\section{Siklus 1}

Seperti yang diungkapkan sebelumnya, siklus pertama terdiri dari 4 pertemuan. Di pertemuan 1-4 ini siswa diberikan materi dan latihan. Setelahnya, siswa diberikan review sekaligus mempraktekkan permainan. Terakhir, siswa diberikan posttest untuk mengecek perkembangan penguasaan kosakata mereka setelah tindakan. Hasil pengamatan dan hasil tes siswa dijelaskan sebagai berikut.

Hasil pengamatan siklus 1 menunjukkan beberapa hasil sekaligus kelemahan dari pelaksanaan tindakan pada siklus 1, yaitu:

a. Siswa masih kurang berani untuk menunjukkan peran aktif mereka di kelas, baik bertanya, menjawab maupun maju ke depan kelas. Mereka umumnya hanya berani maju ke depan kelas jika bersama-sama dengan kelompok mereka.

b. Siswa masih bingung dengan instruksi dan penjelasan pada setiap jenis permainan yang dipakai di kelas sehingga guru harus memberikan penjelasan yang lebih konkrit.

c. Siswa membutuhkan waktu yang lebih banyak untuk mengerjakan soal dan latihan. Hal ini dikarenakan waktu belajar di kelas tersita oleh sesi untuk menjelaskan instruksi permainan sehingga hanya ada sedikit waktu untuk mengerjakan soal atau latihan. Karenanya, peneliti berusaha menjelaskan dengan bahasa

d. yang lebih sederhana dan konkrit agar siswa mengerti.

e. Soal dan latihan yang diberikan pada siswa tidak dibahas secara mendalam.

Semua tahapan dan kegiatan yang dilaksanakan pada siklus 1 ini kemudian 


Kredo 4 (2021)
KREDO: Jurnal Ilmiah Bahasa dan Sastra
Terakreditasi Sinta 4 berdasarkan Keputusan Direktorat
Jenderal Penguatan Riset dan Pengembangan,
Kementerian Riset, Teknologi dan Pendidikan Tinggi
Republik Indonesia
Nomor: 23/E/KPT/2019. 08 Agustus 2019
https://jurnal.umk.ac.id/index.php/kredo/index

dianalisis dan dievaluasi oleh peneliti bersama dengan kolaborator. Hasil evaluasi ini kemudian dijadikan acuan untuk menentukan rencana tindakan pada siklus berikutnya. Tanggapan dan kesan siswa yang didapat dari data wawancara dan kuisioner pun dijadikan pertimbangan dalam menentukan perencanaan di siklus berikutnya. Beberapa hal yang masih harus diperbaiki yaitu:

a. Siswa harus lebih banyak diberikan motivasi oleh peneliti untuk berpartisipasi aktif selama proses belajar berlangsung.

b. Siswa harus diberikan penjelasan tentang aturan permainan dengan bahasa yang lebih jelas, sederhana dan konkrit. Penggunaan media sangat disarankan untuk membantu pelaksanaan permainan di kelas.

c. Penggunaan waktu baiknya direncanakan dengan lebih efektif dan efisien sehingga waktu yang dialokasikan bisa dimanfaatkan dengan sebaik-baiknya.

d. Soal dan latihan baiknya dibahas dengan detail dan meyeluruh dengan tujuan untuk memaksimalkan fungsi soal dan latihan untuk mengulang materi yang sudah diberikan.

Adapun hasil posttest di siklus 1 menunjukkan hasil yang relatif rendah yakni dengan rata-rata 62,54. Hasil ini dikatakan masih kurang karena belum semua siswa mampu mencapai KKM
(70). Dari 22 orang siswa, hanya 3 orang (14\%) yang nilainya mencapai KKM. Sementara $86 \%$ dari siswa nilainya masih di bawah KKM.

Hasil tes siklus 1 digambarkan pada grafik berikut ini.

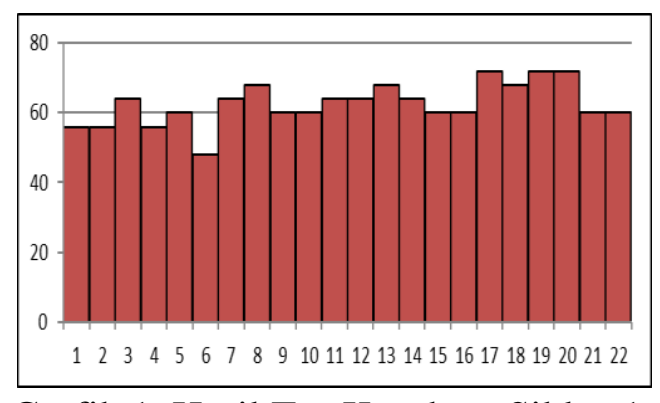

Grafik 1. Hasil Tes Kosakata Siklus 1

Grafik di atas menunjukkan nilai terendah yang diperoleh siswa masih di bawah 60 , tepatnya 48 . Sementara nilai tertinggi yang diraih siswa adalah 72 , masih kurang beberapa poin dari KKM.

Melihat hasil tersebut serta evaluasi tahapan dan kegiatan yang disebutkan sebelumnya, maka peneliti dibantu oleh kolaborator melanjutkan penelitian tindakan di siklus 2 .

\section{Siklus 2}

Sama seperti pelaksanaan siklus 1 , siklus 2 dilaksanakan dalam 4 pertemuan. Pertemuan ke 5 digunakan untuk praktek penggunaan permainan, dan pertemuan keenam untuk pelaksanaan posttest. Soal yang diteskan pada posttest siklus 2 ini sama dengan yang digunakan di siklus 1 namun dengan sedikit perubahan pada nomor 


Kredo 4 (2021)
KREDO: Jurnal Ilmiah Bahasa dan Sastra
Terakreditasi Sinta 4 berdasarkan Keputusan Direktorat
Jenderal Penguatan Riset dan Pengembangan,
Kementerian Riset, Teknologi dan Pendidikan Tinggi
Republik Indonesia
Nomor: 23/E/KPT/2019. 08 Agustus 2019
https://jurnal.umk.ac.id/index.php/kredo/index

urut dan pengacakan pilihan jawaban. Setelah posttest selesai dilaksanakan, tahap terakhir yang dilakukan adalah wawancara tahap akhir pada siswa.

Hasil pengamatan di siklus kedua ini siswa menunjukkan partisipasi aktif dan kreatif serta inovatif selama proses belajar mengajar berlangsung. Siswa sudah tidak merasa malu, takut, ataupun kurang percaya diri. Perasaan ini semua hilang dan berubah menjadi keberanian. Para siswa sudah berani bertanya dan menjawab, berbicara, dan kemampuan bahasa Inggris merekapun meningkat.

Sementara itu, hasil tes di siklus 2 pun menunjukkan kenaikan nilai yang signifikan di mana semua siswa (100\%) mencapai nilai di atas KKM dengan ratarata nilai 84,90. Grafik berikut menunjukkan hasil tes siswa pada siklus 2.

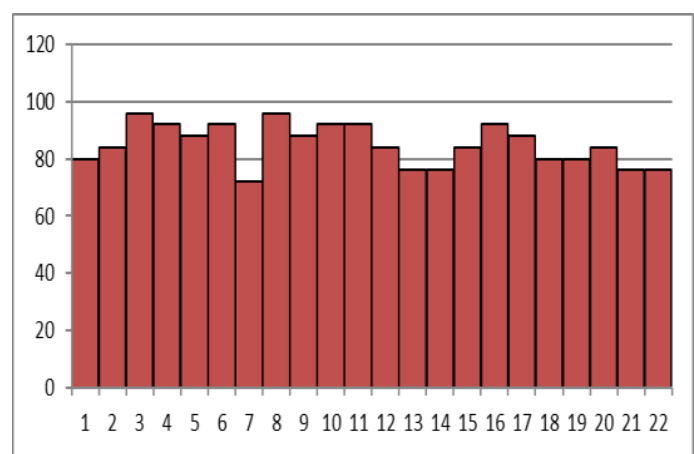

Grafik 2. Hasil Tes Kosakata Siklus 2

Grafik 2 di atas memperlihatkan nilai siswa melebihi KKM. Nilai terendah yang didapat siswa adalah 72 , sementara nilai tertinggi adalah 96. Melihat hasil tes yang sudah melampaui KKM, maka penelitian dicukupkan sampai siklus 2 .

Adapun poin-poin hasil evaluasi siklus 1 berhasil dilaksanakan di siklus 2. Adanya perbaikan ini membawa banyak dampak positif terhadap proses dan hasil pembelajaran siswa. Keberhasilan ini mengarah pada kesimpulan bahwa:

1. Permainan bahasa bisa memperluas penguasaan kosakata bahasa Inggris siswa sekolah dasar.

2. Permainan bahasa mampu meningkatkan keberanian, kreativitas dan inovasi siswa untuk berpartisipasi aktif dalam pembelajaran.

3. Pelaksanaan tindakan meningkatkan pemahaman siswa mengenai pentingnya penguasaan kosakata bahasa Inggris untuk menunjang.

4. keterampilan berbahasa dan berkomunikasi.

5. Penggunaan permainan bahasa di kelas memotivasi siswa untuk mengikuti pembelajaran dengan lebih serius dan sungguh-sungguh.

\section{Efektivitas Permainan Bahasa}

Hasil posttest dari siklus 1 dan 2 dianalisis menggunakan uji $\mathrm{t}$ untuk mengetahui sejauh mana efektivitas 


Kredo 4 (2021)
KREDO: Jurnal Ilmiah Bahasa dan Sastra
Terakreditasi Sinta 4 berdasarkan Keputusan Direktorat
Jenderal Penguatan Riset dan Pengembangan,
Kementerian Riset, Teknologi dan Pendidikan Tinggi
Republik Indonesia
Nomor: 23/E/KPT/2019. 08 Agustus 2019
https://jurnal.umk.ac.id/index.php/kredo/index

penggunaan permainan bahasa sebagai media pembelajaran di kelas.

Hasil perhitungan data kuantitatif dengan menggunakan uji t untuk sampel nonindenpenden diperoleh $\mathrm{t}$ hitung sebesar 13.63. Kemudian hasil tersebut diinterpretasikan dengan $\mathrm{t}$ tabel pada taraf nyata $\alpha 0.05(0.686)$ dan $\quad \alpha 0.01$ (1.721) sehingga diketahui bahwa $0.686 \leq 13.63 \geq$

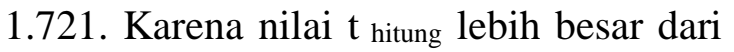
$\mathrm{t}_{\text {tabel, }}$ maka hasil pengujian dinyatakan sangat signifikan. Dengan demikian dapat dikatakan bahwa terdapat peningkatan hasil pretest dengan posttest penguasaan kosakata bahasa Inggris siswa kelas IV SD Model Insan Madani Bekasi.

Hasil perhitungan data kuantitatif yang didapat dari hasil tes serta data kualitatif yang dikumpulkan dari observasi, wawancara dan kuisioner menunjukkan adanya peningkatan penguasaan kosakata bahasa Inggris siswa Permainan bahasa di laboratorium multimedia Town4kids ini juga memberikan efek positif yang cukup efektif hasil belajar siswa. Selain itu, ditemukan juga bahwa secara umum permainan bahasa yang ada di laboratorium multimedia Town4kids ini menciptakan pembelajaran yang lebih dinamis dan menyenangkan untuk siswa. Pembelajaran ini menjadi lebih meaningful karena ada kecocokan antara karakteristik permainan dengan sifat dasar anak-anak di sekolah dasar yang menyukai permainan. Modernisasi dalam pembelajaran juga cukup mendominasi dengan penggunaan permainan bahasa ini.

Dengan demikian, bisa dikatakan bahwa penggunaan permainan bahasa dalam laboratorium multimedia Town4kids efektif dalam meningkatkan kemampuan penguasaan kosakata bahasa Inggris siswa serta memberikan pengaruh positif dalam partisipasi aktif siswa di kelas.

\section{SIMPULAN}

Hasil analisis dan interpretasi dari tes, observasi, wawancara dan kuisioner menunjukkan bahwa kemampuan penguasaan kosakata bahasa Inggris siswa kelas IV SD Model Insan Madani meningkat dengan penggunaan permainan bahasa yang bervariasi di laboratorium. Peningkatan penguasaan kosakata ini menunjukkan efektivitas penggunaan permainan bahasa yang dianalisis lewat uji statistika. Permainan bahasa inipun mampu menciptakan pembelajaran yang dinamis dan menyenangkan sehingga siswa mau berpartisipasi aktif dalam proses pembelajaran.

Berdasarkan kesimpulan di atas, beberapa hal perlu diperhatikan sebagai saran dari penelitian ini:

1. Guru seyogyanya harus mampu mengupgrade kompetensi dalam sejumlah hal berikut; 1) penggunaan media dalam pembelajaran di kelas; 2) manajemen kelas; 3) gaya belajar diusahakan lebih student-centered di 


Kredo 4 (2021)
KREDO: Jurnal Ilmiah Bahasa dan Sastra
Terakreditasi Sinta 4 berdasarkan Keputusan Direktorat
Jenderal Penguatan Riset dan Pengembangan,
Kementerian Riset, Teknologi dan Pendidikan Tinggi
Republik Indonesia
Nomor: 23/E/KPT/2019. 08 Agustus 2019
https://jurnal.umk.ac.id/index.php/kredo/index

mana guru lebih berperan sebagai fasilitator; dan 4) pemahaman terhadap gaya belajar siswa sekaligus optimalisasinya.

2. Bagi peneliti yang akan melakukan penelitian tindakan dengan fokus yang sama harus membuat perencanaan penelitian dengan materi yang cukup dan pengaturan waktu yang baik.

\section{DAFTAR PUSTAKA}

Djiwandono, M. S. 2008. Tes Bahasa: Pegangan bagi Pengajar Bahasa. PT Indeks.

Finegan, E. 2008. Language: Its Structure And Use. Thomson Wadsworth.

Gay, L. R., \& Mills, G. E. 2009. Educational Research: Competencies For Analysis And Applications. Pearson.

Hadfield, J. 2009. Elementary Vocabulary Games. Pearson Education Limited.

Harmer, J. 2007. The Practice Of English Language Teaching. Longman, Inc.

Heaton, J. B. 1975. Writing English Language Tests. Longman.

Hornby, A. S. 1994. Oxford Advanced Learner's Dictionary Of Current English. Oxford University Press.

Kemmis, S., \& Mctaggart, R. 1982. The Action Research Planner. Deakin University.

Madya, S. 1994. Panduan Penelitian Tindakan. Lembaga Penelitian IKIP Yogyakarta.

Mills, G. E. 2003. Action Research: A Guide For The Teacher Researcher. Pearson Education Limited.

Munir, M. 2009. Multimedia Konsep Dan Aplikasi Dalam Pendidikan. Alfabeta. 


Kredo 4 (2021)
KREDO: Jurnal Ilmiah Bahasa dan Sastra
Terakreditasi Sinta 4 berdasarkan Keputusan Direktorat
Jenderal Penguatan Riset dan Pengembangan,
Kementerian Riset, Teknologi dan Pendidikan Tinggi
Republik Indonesia
Nomor: 23/E/KPT/2019. 08 Agustus 2019
https://jurnal.umk.ac.id/index.php/kredo/index

O’Grady, W. 2005. How Children Learn Language. Cambridge University Press.

Richards, J. C., \& Renandya, W. A. 2003. Methodology In Language Teaching: An Anthology Of Current Practice. Cambridge University Press.

Slavin, R. E. 2006. Educational Psychology: Theory And Practice. Pearson Education, Inc.

Thomson, A. J., \& Martinet, A. V. 1986. A Practical English Grammar. Oxford University Press. 